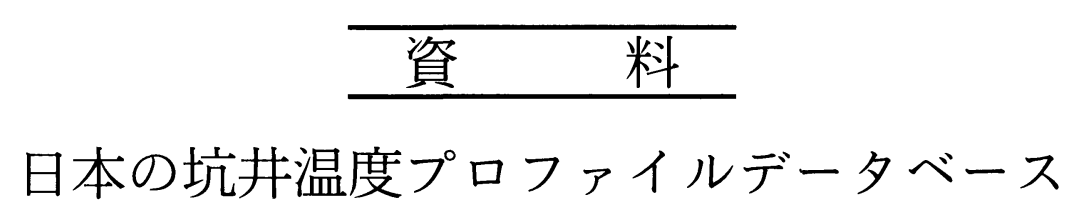

核燃料サイクル開発機構東濃地科学センタ一地質環境研究グループ* 坂 川 幸 洋・梅 田浩司

株式会社ペスコ中部事務所** 鈴 木 元 孝

地熱エンジニアリング株式会社探查部*** 梶 原 竜 哉

独立行政法人 産業技術総合研究所 地質調查総合センター**** 内田洋平

\title{
Database on the Temperature Profiles of Boreholes in Japan
}

\section{Yukihiro SAKAGAwa and Koji Umeda}

Geoscience Research Group, Tono Geoscience Center, Japan Nuclear Cycle Development Institute, 959-31, Jorinji, Izumi, Tokishi, Gifu 509-5102, Japan

\section{Mototaka SuzuKI}

Chubu Office, Pesco Co., Ltd., \#301, Mino Bldg. '92, 25, Minamimachi 3-chome, Tokiguchi, Toki, Gifu 509-5123, Japan

\section{Tatsuya KaJIWARA}

Exploration Department, JMC Geothermal Engineering Co., Ltd., Hosoyachi 101-1, Ukai,

Takizawa-mura, Iwate-gun, Iwate 020-0172, Japan

\section{Youhei UcHidA}

Water Environment Research Group, Geological Survey of Japan, AIST, AIST Tsukuba Central 7, Tsukuba, Ibaraki 305-8567, Japan

(Received December 24, 2003; Accepted March 16, 2004)

\section{§1.はじめに}

坑井温度プロファイルから地下の温度構造や熱流量, 地下水流動, 地表面温度変動が解析できることが知られ ている. 本データベースはそれら解析の基礎資料とする 目的で作成した.

日本全国の石油井, 地熱井, 地殼活動の観測井, 地方 自治体などが管理している地盤沈下対策用観測井, 温泉 井などの坑井温度プロファイルを収録している。 また, 可能な限り熱伝導率や温度プロファイル測定条件む調査

* \%509-5102 土岐市泉町定林寺 951-31

** テ509-5123 土岐市土岐口南町 3 丁目 25 番地 美濃ビル'92 301 号室

*** =020-0172 岩手郡滝沢村鵜飼字細谷地 101-1

**** \% 305-8567 つくば市東 1-1-1 中央第 7
し記載した。

\section{§2. データベース作成の経緯}

矢野・他 (1999) は日本全国の温泉井, 地熱井など 1,936 本の坑井について坑底温度などを調査し，日本列 島地温勾配図を作成した，個別坑井のデー夕（緯度, 経 度, 標高, スタンディングタイム, 坑井深度, 坑底温度, 地温勾配)については田中・他 (1999) によって公表さ れているものの, 深度ごとの温度デー夕(いわゆる温度 プロファイル）は示されていない. また, 谷口・他 (2003) は気候・水文変動を推定することを目的に，(1) 浅層地下水温鉛直分布デー夕（約 500 本, 深度 $50 \mathrm{~m}$ か ら数百 $\mathrm{m}),(2)$ 日本全国 61 力所の農業気象官署におけ る地温連続測定 デー夕 (深度 $10 \mathrm{~m}$ ), (3) 孔底温度 (1,937 デー夕 (地質調查所), 深度約 $6 \mathrm{~km}$ まで) の 3 種 
類のデータを統合し，データベースの構築を試みた． 温 度プロファイルが明らかであれば, 地温勾配のほか, 深 度ごとの流体の流動の特徵や流体流動を考慮した熱輸送 などを推定することが可能となる．温度プロファイルが 上昇流型，すなわち上に凸であれば熱伝導に加えて上昇 する流体によっても熱が浅方に運ばれている．この移流 項は, 主として温度プロファイルの曲率, すなわち地温 勾配の深度変化率から求めることができる [例えば, Bredehoeft and Papadopulos (1965)]. 地表面温度が変 動すると, 熱伝導により地下温度分布が変化する. パル ス変動の影響を考えると, 古い変動ほど温度変化の最大 幅が小さく温度变化を被る深度が深くなる．実際の地表 面温度変化はパルス変動の積分で表せるので, 地下温度 分布変化をパルス応答と地表面温度変化の盢み込み積分 でモデル化するとき，地下温度分布には地表面温度変化 に関する情報が豊富に含まれていると考えることができ る.したがって，地下温度分布が流体流動の影響を受け ておらず, 温度プロファイルのデー夕の分解能・精度が 高いなどの条件が揃えば地表面温度变動を求めることが できる [例えば, Beck (1982), Lachenbruch and Marshall (1986), Kukkonen and Clauser (1994), Sakura et al. (1996), Taniguchi et al.(1999)]. 近年, 温度プロ ファイルを利用して移流項を解析，また，気候変動を解
析しようとする機運が高まってきているため，本データ ベースを公開することにした.

梅田・他 (2003) は矢野・他 (1999), 田中・他 (1999) のデータに須田・矢野 (1991), 北海道立地下資源調査所 (1995), 棚田 (1997), 山野・他 (1997) の坑井デー夕, 地 熱 [新エネルギー・産業技術総合開発機構 (2002)] およ び地下水の分野における既存公表文献などより収集した データを追加し, 流体流動の寄与を加味して熱流量を解 析した. その際, 温度プロファイルが不明な坑井は除外 した. また，浅い坑井では温度測定誤差の影響で地温勾 配の算定誤差が大きく, 地下水流動などによる温度の擾 乱が激しいため, 掘削深度が $300 \mathrm{~m}$ 末満の坑井も除外 した. その結果, 坑井数は 1,215 本となった. 本デー夕 ベースは梅田・他 (2003) がコンパイルしたデータを データベース化したものである.

\section{3. データベースの概要}

本データベースは坑井名, 坑井所在地, 坑口座標, 温 度プロファイル測定条件, 出典などの付帯情報と温度プ ロファイルの数值データからなる.

付帯情報は全坑井分をファイルメーカー用のファイル (ランタイム版) にまとめた. 付帯情報は坑井番号, 都道 府県名, 地点名, 温泉名・坑井名, 掘削年月日, 最終坑

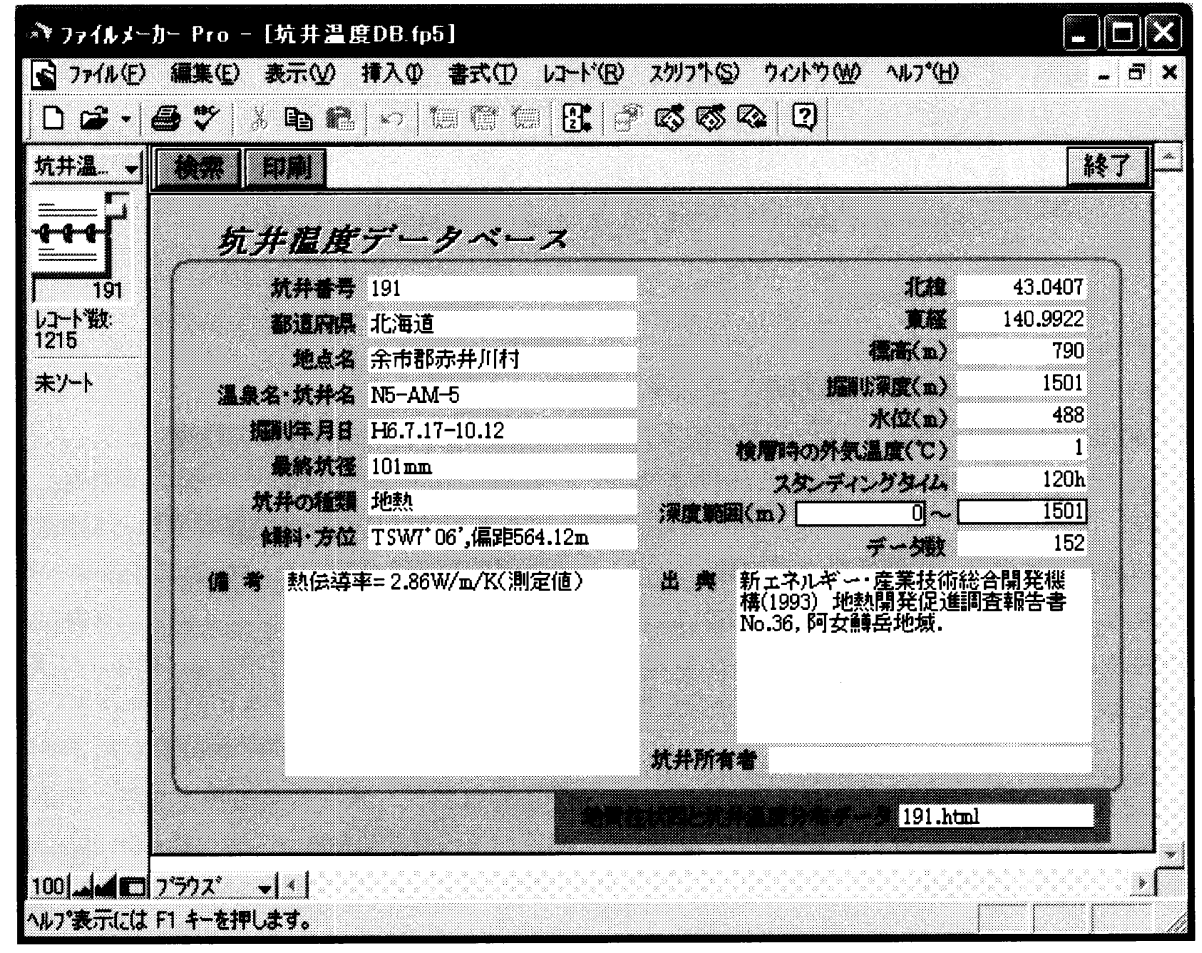

Fig. 1. An example image of well-bore information associated with well-bore temperature profile. 


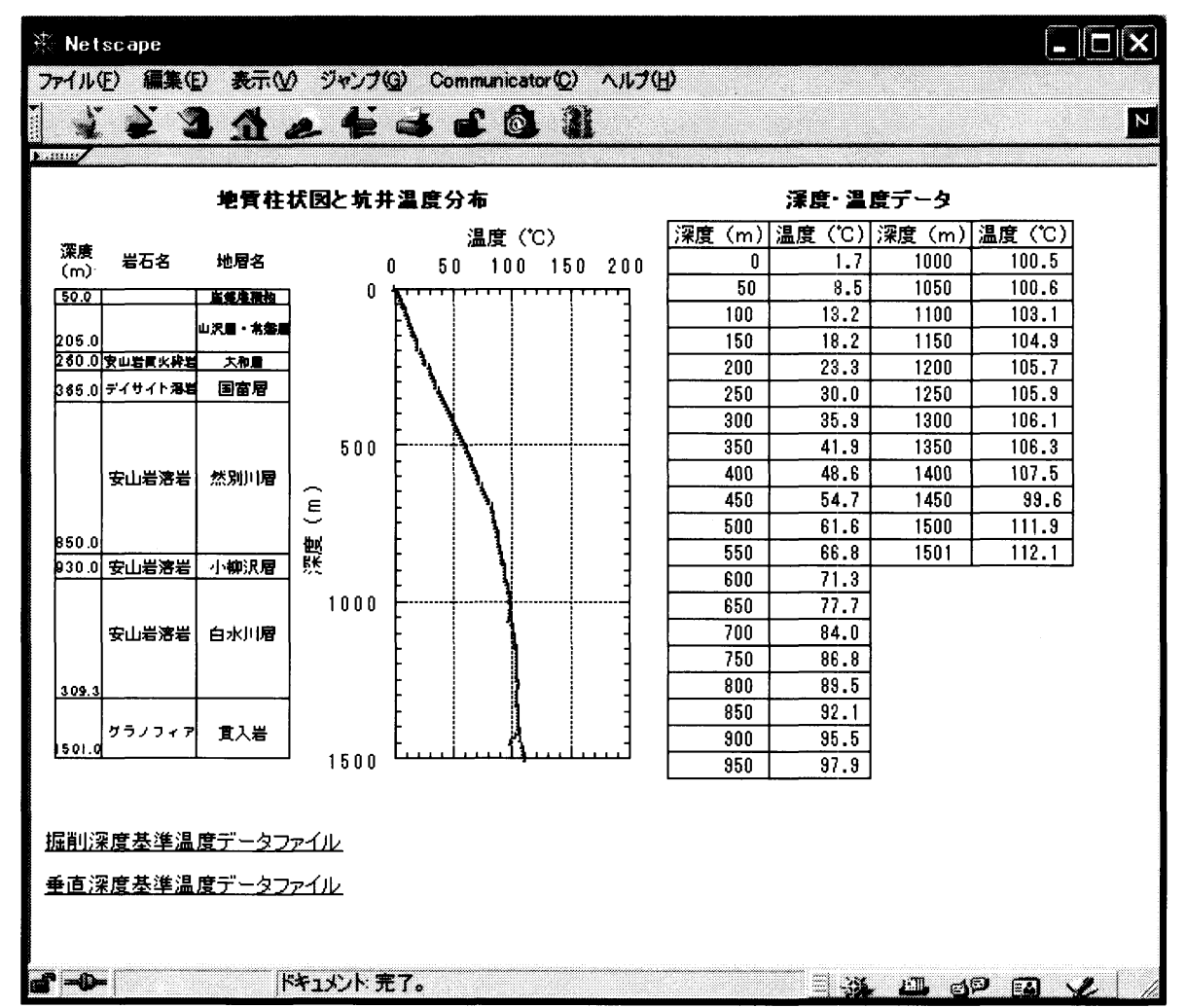

Fig. 2. An example image of geological column and well-bore temperature profile.

Table 1. The Basis of Thermal Conductivity.

\begin{tabular}{|l|l|l|}
\hline ケース & 熱伝導率の与え方 \\
\hline 対象坑井で熱伝導率の測定結果がある場合 & 対象坑井の熱伝導率の平均值を用いる \\
\hline $\begin{array}{l}\text { 対象坑井で熱伝導率の測定 } \\
\text { 結果がない場合 }\end{array}$ & 地質柱状図あり & $\begin{array}{l}\text { 解析対象区間*を代表する岩石を抽出し, その岩石の熱伝 } \\
\text { 導率の平均值を用いる }\end{array}$ \\
\cline { 2 - 3 } & 地質柱状図なし & $\begin{array}{l}\text { JNCが作成した地質分布図を基にして, 岩石名を特定 } \\
\text { し, その平均值を用いる }\end{array}$ \\
\hline
\end{tabular}

*: 坑井温度プロファイルが Bredehoeft and Papadopulos (1965)の一次元熱輸送モデルに当てはまる深度区間. 坑口から坑底の大部分を占める場合が多い.

径, 坑井の種類, 傾斜 - 方位, 坑口座標, 掘削深度, 検 層時の坑内水位, 検層時の外気温度, スタンディング夕 イム（掘削などの作業後坑井を放置し, 坑井温度を回復 させた時間), 温度デー夕の深度範囲およびデー夕数, 備 考, 出典, 岩相分布からなる (Fig. 1, 2). Fig. 1 はファイ ルメーカーの「フォーム形式」表示であり, Fig. 2 は Fig. 1 の「地質柱状図と坑井温度分布デー夕」欄をク リックすると現れる Web ブラウザによる情報表示であ る.

坑井番号は北から順, 緯度が同じ坑井群については東
から順に付けた。 公表文献からの収録でなく地方自治体 や民間企業などから提供を受けたデー夕については，そ の旨を記した。

また, 岩石の熱伝導率をできる限り調へ備考欄に記載 した，熱伝導率は, 測定值がある場合には測定值を記載 し, 測定値がない場合には岩石の種類を基に推定して記 載した (Table 1).なお, 熱伝導率の整理には, 矢野・他 (1989), 岩石物性值データベース PROCK [須田・他 (1991)］およびこれらに含まれない NEDO 地熱開発促 進調查に扔ける測定結果を用いた。 


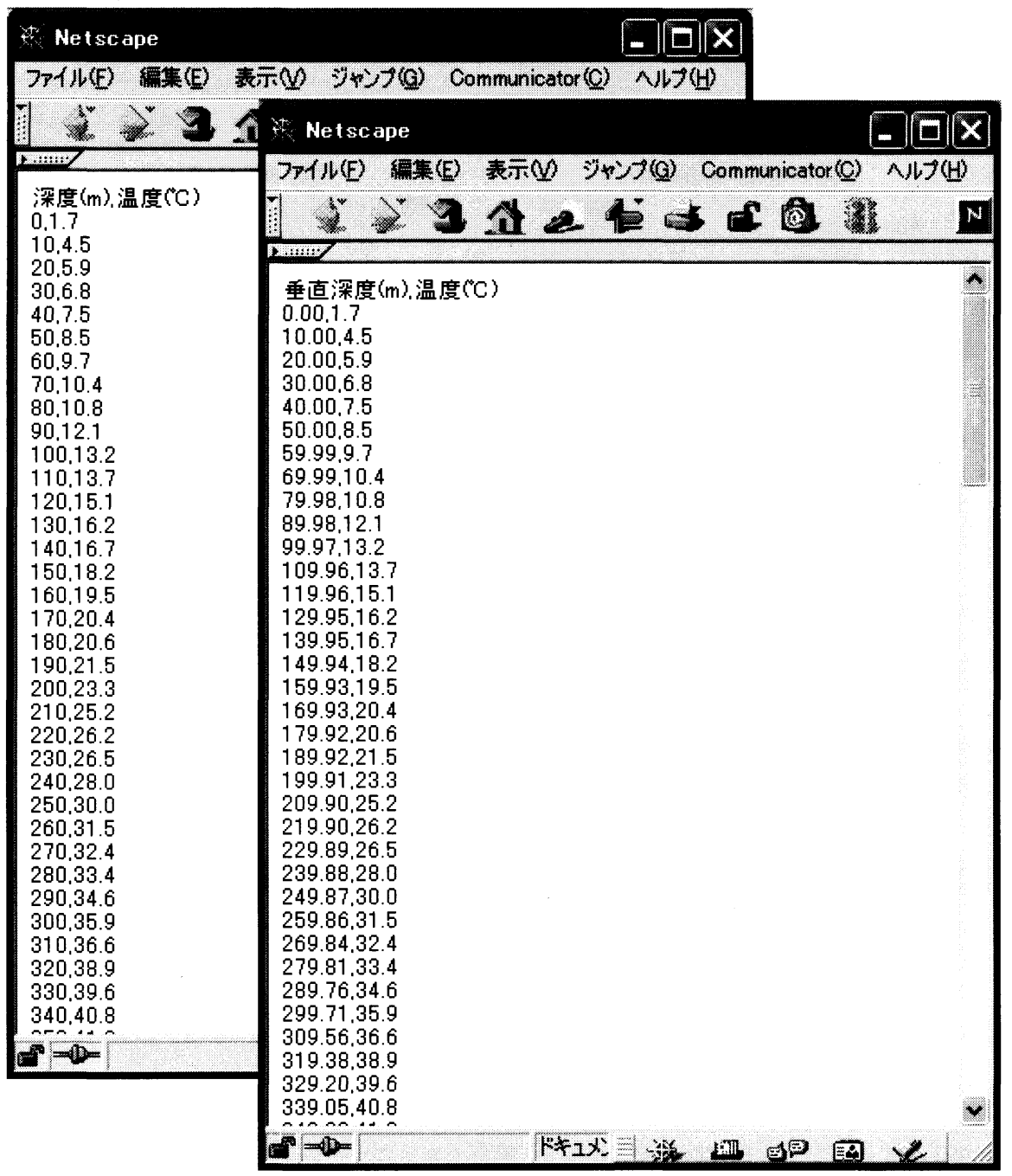

Fig. 3. An example image of detailed data of well-bore temperature profile displayed in Web browser.

Fig. 2 の Web ページには坑井温度プロファイルの数 值データファイルへのリンクがあり，これを用いて数值 データをWeb ブラウザに表示させたりファイルをコ ピーすることが可能である．数值データを別ウィンドウ に表示させた例を Fig. 3 に示す.

温度プロファイルの数值デー夕は基本的に 1 坑井に つき 1 ファイルである. 坑井によっては複数回に分けて 測定が行われているものがあり，そのような坑井に対し てはデータをテキストファイル中，縱列に連結した．ま た，坑跡データが入手できた坑井については，通常の深 度対温度のファイルのほか, 垂直深度対温度のファイル も収録している (Fig. 2，3). 坑跡データが入手できな かった坑井については，傾斜井であっても垂直深度対温
度のファイルは収録されていない。

本データベースのユーザーは緯度や経度の範囲を指定 し，その範囲に入る坑井のみに限定して表示することが できる。

\section{§4. おわりに}

本データベースは Windowsのコンピュータと Macintosh のコンピュータで利用できる（希望者は http:// www.jnc.go.jp/ztounou/siryou/welltempdb.html か らダウンロードしていただきたい).

本データベースでは, 各坑井で熱伝導率を平均化して 記載した．今後, プロファイルデー夕化することで利用 者の利便を図りたい。 
末筆ながら, 本データベースが地球熱学や気候変動学 など固体地球科学諸分野の発展にわずかながらであ寄与 することを願う。

\section{謝 辞}

本データベースの作成にあたり, 産業技術総合研究 所, 北海道立地下資源調查所, 新エネルギー・産業技術 総合開発機構, 石油公団, 防災科学技術研究所, 新工齐 ルギー財団，地熱エンジニアリング，三菱マテリアル資 源開発，地方自治体执よび坑井所有者の方々には多大な る協力をいただいた。 また, 東京大学地震研究所の山野 誠氏およびほか 1 名の匿名の查読者には, 原稿の不備な 点をご指摘いただくとともに建設的なご意見をいただい た。これらの方々に感謝いたします。

\section{参考文献}

Beck, A. E., 1982, Precision logging of temperature gradients and the extraction of past climate, Techtonophysics, 83, 1-11.

Bredehoeft, J. D. and I. S. Papadopulos, 1965, Rates of vertical groundwater movement estimated from the earth's thermal profile, Water Resour. Res., 1, 325-328.

北海道立地下資源調査所, 1995,60 万分の 1 北海道地 温勾配図。

Kukkonen, I. T. and C. Clauser, 1994, Simulation of heat transfer at the Kola deep-hole site: Implications for advection, heat refraction and paleoclimate effects, Geophys. J. Int., 116, 409-420.

Lachenbruch, A. H. and B. V. Marshall, 1986, Changing climate: Geothermal evidence from permafrost in the Alaskan Arctic, Science, 234, 689-696.

Sakura, Y., Y. Uchida and M. A. Anderson, 1996, Effect of groundwater flow and surface warming on the subsurface thermal regime in the Nobi Plain around Nagoya, central Japan, Eos Trans. Am. Geophys. Union, 77, Spring Meet. Suppl., S97.
新エネルギー・産業技術総合開発機構, 2002, 坑井デー 夕管理システム $(\mathrm{CD}-\mathrm{R})$.

須田芳朗・村田泰章・菊地恒夫・花岡尚之, 1991, 岩石 物性値データベース (PROCK), 地質調查所研究資料 集, $155,231 \mathrm{pp}$.

須田芳朗・矢野雄策, 1991, 日本の地熱調查における坑 井デー夕その 2 検層データおよび地質柱状図デー 夕，地質調查所報告, $273,842 \mathrm{pp}$.

棚田俊収, 1997, 箱根火山を含む伊豆半島北東部におけ る地震活動， 3 次元 $\mathrm{P}$ 波速度構造および地中温度分布 について，地質二ュース， 517，38-41.

田中明子 - 矢野雄策 - 笹田政克 - 大久保泰邦 - 梅田浩 司・中司 昇・秋田藤夫, 1999 , 坑井の温度デー夕に よる日本の地温勾配値のコンパイル, 地質調査所月 報, 50, 457-487.

Taniguchi, M., J. Shimada, T. Tanaka, I. Kayane, Y. Sakura, Y. Shimano, S. Dapaah-Siakwan and S. Kawashima, 1999, Disturbances of temperaturedepth profiles due to surface climate change and subsurface water flow: 1 . An effect of linear increase in surface temperature caused by global warming and urbanization in the Tokyo metropolitan area, Japan, Water Resour. Res., 35, 15071517.

谷口真人・佐倉保夫 - 内田洋平 - 宮越昭暢, 2003 , 日本 における地下温度デー夕ベースの構築一気候・水文変 動の評価にむけて一, 地球惑星科学関連学会 2003 年 合同大会, T032-001 (CD-ROM).

梅田浩司・梶原竜哉・内田洋平, 2003 , 日本列島におけ る坑井温度プロファイルのコンパイルと一次元熱輸送 モデルによる熱流束, 地球惑星科学関連学会 2003 年 合同大会, T032-P002 (CD-ROM).

山野 誠・木下正高 - 山形尚司, 1997, 日本列島周辺海 域の地殼熱流量分布，地質二ュース，517，12-19.

矢野雄策・須田芳朗・玉生志郎, 1989, 日本の地熱調査 における坑井データ その 1 コア測定データ一物性, 地質層序，年代，化学組成一，地質調查所報告， 271, $832 \mathrm{pp}$.

矢野雄策 - 田中明子・高橋正明 - 大久保泰邦 - 笹田政 克 - 梅田浩司 - 中司 昇, 1999, 日本列島地温勾配 図, 地質調査所. 